\title{
Development and Performance of Pipe Framed Hydroponic Structure for Fodder Crop: A Review
}

\author{
Rahul G. Tayade ${ }^{1 *}$ and Sonali J. Chavan ${ }^{2}$ \\ ${ }^{1}$ Department Farm Structure, ${ }^{2}$ Department of Irrigation and Drainage Engineering, College \\ of Agriculture Engineering and Technology, Jalagaon Jamod, India \\ *Corresponding author
}

\section{A B S T R A C T}

Key words

Hydroponic Structure, Shade net, Automization, Trays, Nutrient content

Article Info

Accepted:

04 October 2018

Available Online:

10 November 2018
The Study entitled with "Development and Performance evaluation of Pipe Framed Hydroponic Structure for Fodder crop" was conducted for period of 120 days at Department of Farm structure, Hydroponic structure was constructed using U-PVC Pipes with external dimensions such as $3 \mathrm{~m}$ height $\mathrm{x} 2 \mathrm{~m}$ width $\mathrm{x} 3 \mathrm{~m}$ length and it consist of six internal rack structure with size of $0.45 \mathrm{~m}$ height $\times 0.45 \mathrm{~m}$ width $\mathrm{x} 0.8 \mathrm{~m}$ length. The internal structure was equipped with 54 plastic hydroponic trays with size of $0.45 \mathrm{~m}$ length $\times 0.30 \mathrm{~m}$ width $\times 0.15 \mathrm{~m}$ height, which was equipped with semi-automated sprayer irrigation. Hydroponic structure was covered with $50 \%$ UV stabilized shade net. In order to control the internal temperature of hydroponic structure, proper spraying of water was carried out at regular interval per day automatically to get a range of 25 - 300C temperature and $65-70 \%$ relative humidity. It was observed that in hydroponic structure the biometric characters such as plant height $28.55 \mathrm{~cm}$, weight of tray $(5.50 \mathrm{Kg}$ per tray)

\section{Introduction}

\section{History of hydroponics}

The word hydroponics has been derived from the Greek word 'water working'. Hydro means 'water' and ponic means 'working' and it is a technology of sprouting grains or growing plants without soil, but only with water or nutrient rich solution. However, hydroponics fodder can be well produced with the use of fresh water only and the use of nutrient rich solution is not obligatory. The added expenses of the nutrient solution also do not justify its use rather than the fresh water, unless there is significant improvement in the feeding value of the hydroponics fodder due to the use of the nutrient solution. A shade net house is a framed or inflated structure covered with a transparent or translucent material in which the crops could be grown under the conditions at least partially controlled environment and which is large enough to permit a person to work within it to carry out cultural operations (Chandra and Gupta, 2003).

Hydroponic fodder production is a technique of growing crops such as barley, cowpea, sorghum, wheat, maize etc. in a hygienic environment free of chemicals like insecticides, herbicides, fungicides, and 
artificial growth promoters Al-Karaki and AlHashimi (2010). It is a well-known technique for high fodder yield, year round production and less water consumption. It has been reported that about 1.5-2 litres are needed to produce $1 \mathrm{Kg}$ of green fodder hydroponically in comparison to 73,85 , and 160 liters to produce $1 \mathrm{Kg}$ of green fodder of barley, alfalfa, and Rhodes grass under field conditions, respectively (Naik et al., 2015). Fodder produced hydroponically has a short growth period 8-12days and requires only a small piece of land for production to take place.

It has high feed quality, rich with proteins, fibers, vitamins, and minerals with therapeutic effects on animals. All these special features of hydroponic culture, in addition to others make it one of the most important agricultural techniques currently in use for green forage production in many countries especially in arid and semi-arid regions. Barley (Hordeum vulgare) harvested as feed and hay is a significant source of forage for livestock producers in most arid and semiarid regions because it can be an inexpensive and readily available feed source. Forage barley has good yield and has been found to have higher nutritive value and lower fiber concentration than other small grains (Al-Karaki and AlHashimi, 2010).

Proper feeding and good balanced rations remains the cornerstone of a successful dairy operation. Milk yield per cow and the cost of feed to produce milk have been the greatest influence on profitability in dairy operation. If dairy farming is to be successful, the dairymen must continually strive to adopt technologies that allow the greatest output of milk at the most economical cost. Successful dairying in the future will depend on high levels of milk production, culling for low production, controlling feed costs, and using good replacements (Staal and Pratt, 2010).
Hydroponics fodder can also be produced in low cost greenhouses or device. The low cost greenhouses or shade net structures can be prepared from bamboo, wood, MS steel or galvanized iron steel. The cost of the shade net structures depends upon the type of fabricating material but is significantly lower than the hi-tech greenhouses. One side wall of the house can be used to construct lean-toshade net structure which reduces the cost of fabrication (Naik et al., 2013).

\section{Hydroponic structure}

Fodder grown by the hydroponic method is a source of vitamins, enzymes, and mineral substances. This is a biologically nutritious and naturally balanced fodder differing qualitatively from commercial concentrates. The shortage of fodder and its low quality are the main cause of low productivity (Leontovich and Bobro, 2006). The Hydroponics Wheat fodder (HMF) was produced in a hydroponics chamber (shade net house) measuring about $25 \mathrm{ft} \times 10 \mathrm{ft} \times 10$ $\mathrm{ft}$ with a daily production potential of $600 \mathrm{Kg}$ fresh HMF and equipped with automatic sprayer irrigation by tap water. The growth of the fodder crop mainly depends on moisture, temperature, $\mathrm{RH}$ and irrigation. Hence an automatic time controller is used to control the operation of hydroponic system for switching water pump, battery charge, discharge state and automatic micro sprinklers will be used to control moisture, temperature, $\mathrm{RH}$ and irrigation. The $10^{\text {th }}$ day fodder is harvested and laboratory test were carried out to study the content of crude protein, crude fiber, ether extract, total ash and acid insoluble ash and moisture content. Test revealed that crude protein $(\%)$ 13.2, ether extract $(\%) 3.3$, crude fiber (\%) 15.02, total ash (\%) 2.35, acid insoluble ash (\%) 0.33 and moisture content (\%) 83.87. The increased nutritional content may be due to increased conversion efficiency (Kamat et al., 2018). 
They were studied the research for the adoption of affordable and contextappropriate shade net houses can lead to improved livelihoods for farmers and entrepreneurs while fostering food security (Pack and Mehta, 2012).

The design of the hydroponic structure different parameter considers like loads that act on the shade net house, wind load is the major one. In India, the basic wind speed varies from 33 to $55 \mathrm{~m} / \mathrm{s}$. Along with wind speed, wind load also depend on the geometry, height to width ratio, effective frontal area etc. The design wind pressure estimated to be $772 \mathrm{~N} / \mathrm{m}^{2}$ and wind load on the roof of the shade net house is $222 \mathrm{kN}$ (Suction) and $185 \mathrm{kN}$ (Pressure) (Nayak and Ramanarao, 2014). Hydroponic structure developed the because of low rate of planting and harvesting mechanization is a common drawback of the equipment for hydroponic green fodder (HGF) cultivation. The system, that has been developed, is represented by a rack construction with a tray positioned on each rack; a tray is the place where the processes of seed dispersal and growth and the takeout of grown HGF occur. A tray with a pipe sways in opposite directions over pipe axis, and, as a result, moving bulk of seeds covers the entire tray surface with a seed layer of uniform thickness. The barley seeds with moisture content $10-15 \%$ and the angles of tray tilt $23-25$ degrees should be used during HGF production (Nikolaevna, 2015).

\section{Hydroponic fodder production}

Hydroponic green forage production in a shade net house with plastic containers about $40 \mathrm{~cm}$ lengths, $29 \mathrm{~cm}$ wide and $5.0 \mathrm{~cm}$ height, with a planting area of $0.116 \mathrm{~m}^{2}$. Cultured shelves with and without black polyethylene cover were evaluated. Climate conditions were constant $\left(22{ }^{\circ} \mathrm{C}\right.$ average temperature and $70 \%$ of relative humidity). $520 \mathrm{~g}$ of wheat seed (Triticum aestivum) with 24 hours soaked in water with micronized lime $(\mathrm{CaOH})$ at $50 \%$ were weighted. Watering with simple water were applied during the first four days, the nutrient solution was applied from the $5^{\text {th }}$ day of planting up to the $12^{\text {th }}$ day when the harvest was done. Plant height (HP), yield per $\mathrm{m}^{2}\left(\mathrm{Y} / \mathrm{m}^{2}\right)$ and the conversion relation (RC) were determined (Policarpo et al., 2007).

Poor soil fertility in some of the cultivable areas, less chance of natural soil fertility build-up by microbes due to continuous cultivation, frequent drought conditions and unpredictability of climate and weather patterns, rise in temperature, river pollution, poor water management and wastage of huge amount of water, decline in ground water level, etc. are threatening food production under conventional soil-based agriculture. In soil-less culture, plants are raised without soil. Improved space and water conserving methods of food production under soil-less culture have shown some promising results all over the World (Sardare and Admane, 2013).

Sprouted fodder productions systems at the University of Minnesota's West Central Research and Outreach Center, Morris, MN. Forage mass, mold score, dry matter, and forage quality were evaluated for varieties of sprouted organic barley, oats, wheat, rye, and triticale harvested at $7 \mathrm{~d}$ after the start of sprouting. During September 2014, on every Monday for 6 weeks, 28 fodder trays $(0.6 \mathrm{~m} \mathrm{x}$ $1.8 \mathrm{~m}$ ) from a FarmTek Fodder Pro system were filled with $4.1 \mathrm{~kg}$ of pre-soaked grain, which was soaked for $24 \mathrm{~h}$. Each tray was automatically watered 3 times a day for $4 \mathrm{~min}$ each time. On the seventh day, each tray was harvested, weighed, and visually scored on a 1 to 5 scale for mold by one observer. Concentrations of $\mathrm{CP}$ averaged $15.6 \%$, $13.1 \%, 12.8 \%, 17.0 \%$, and $17.9 \%$ for sprouted barley, oats, rye, and wheat, respectively (Heins et al., 2015). 
Wheat grain should be the choice for production of hydroponics fodder. The hydroponics green fodder looks like a mat of $20-30 \mathrm{~cm}$ height consisting of roots, seeds and plants. To produce one $\mathrm{Kg}$ of fresh hydroponics Wheat fodder about 1.50-3.0 liters of water is required. Yields of 5-6 folds on fresh basis and DM content of 11-14\% are common for hydroponics Wheat fodder, however DM content up to $18 \%$ has also been observed. It is recommended to supplement about 5-10 Kg fresh hydroponics Wheat fodder per cow per day (Naik et al., 2015). Hydroponics cowpea (NB-4) sprouts were produced daily for 15 days in a hydroponics chamber (shade net house) equipped with automatic sprayer irrigation of tap water. The fresh yield $(\mathrm{Kg} / \mathrm{Kg}$ seed $)$ of the hydroponically sprouted cowpea (NB-4) increased with the advancement of growing period and remained similar and highest from day 6 (6.34) to 9 (6.63) growing period. Simultaneously, with the growth of the hydroponics cowpea sprouts, the DM content (\%) decreased and remained similar and lowest from day 8 (6.91) to day 9 (6.49) growing period (Naik et al., 2016). It can be concluded that the seed rate had no effect on the proximate constituents of different portions i.e. roots with germinated seeds, leaves and plants of the HMF. The seed rate of $7.6 \mathrm{Kg} / \mathrm{m}^{2}$ can be recommended for the production of hydroponics Wheat fodder for optimal output and all parts of the hydroponics Wheat fodder are nutritious (Naik et al., 2017).

The feasibility and challenges of implementing sprouted fodder on organic dairy farms. In study 1, 5 grains (barley, oats, wheat, rye, and triticale) were sprouted for $7 \mathrm{~d}$ and analyzed for yield and nutritional content. In study 2, lactating cows were fed a TMR during winter and supplemented with either no fodder or $1.4 \mathrm{Kg}$ (DM) of sprouted barley fodder. In study 3, 3 organic dairies that fed sprouted barley fodder were monitored monthly for 12 mos to collect data on feed nutritional analysis, milk production and composition, and management (Soder et al., 2017).

The biomass yield, physical water productivity and economic water productivity of the six crops taken viz. pearl millet (Pennisetum perpareum), yellow Wheat (Zea mays), Oat (Avena sativa), Barley (Hordeum vulgare), wheat (Triticum aestivum) and white Wheat (Zea mays) which were grown hydroponically to produce fodder. The research was conducted in the April- May, 2016 in PGI farm of Mahatma Phule Krishi Vidyapeeth, Rahuri. For the study a rack of $2.7 \mathrm{~m} \times 1.5 \mathrm{~m}$ area was used made of UVPVC poly pipe with a capacity of holding 54 trays of size $50 \mathrm{~cm} \times 30 \mathrm{~cm} \times 5 \mathrm{~cm}$. factorial complete randomized design were the experimental design used (Lamnganbi and Surve, 2017). The proposed system (Automization system for hydroponics fodder production) was developed for small and medium agriculture explorations enabling fodder production in six days. Within the six days production timeline, the system in completely autonomous, i.e., controls the desired agronomic conditions for production. Moreover, the system controls the fodder flow, i.e., since its entrance (seeds) to the final production stage, trough vertical and horizontal displacement of the fodder trays (Matos et al., 2015).

\section{Hydroponic structure with Automization}

The watering is the most important cultural practice and most labour intensive task in daily shade net house operation. To make the gardener works easily, the automatic plant watering system is created. There have a various type using automatic watering system that are by using sprinkler system, tube, nozzles and other. This project uses watering 
sprinkler system because it can water the plants located in the pots. This project uses Arduino board, which consists of at mega328 Microcontroller (Devika et al., 2014). The automatic system for hydroponics fodder production was designed to produce the fodder in height, to diminish the occupied area in the shade net house, due to the space the later solution occupies, and also to diminish the volume of air to acclimate, if needed.

From the requirements above, is present in the paper the automatic solution that comprises the mechanical structure, the mechanical and hydraulic components, and also the control system to automate the Hydroponic Automatic System (Matos et al., 2015).

The Monitoring and control of agriculture environment play a significant role in agriculture production and management. To monitor the Agriculture environment parameters effectively, it is necessary to design a control system. Here controlling process takes place effectively by automatic manner. For monitor and control purpose, wireless network is used, which will send status of agriculture environment to central station. The main objective is to design a simple, easy to install, Microcontroller-based circuit to monitor and record the values of temperature, humidity, soil moisture, rain measurement and sunlight of the natural environment that are continuously modified and controlled in order optimize them to achieve maximum plant growth and yield (Naik and Shelke, 2016).

The flow of nutrients controlled in hydroponic system by automatically using Arduino microcontroller and controlled by smartphone. We use an Arduino Uno microcontroller to automatically control the flow of nutrient solution with logic if else (Sihombing et al., 2017).

\section{Nutritional evaluation of hydroponically grown fodder}

Hydroponic nutrient solution was used to raise barley sprouts to compare with sprouts raised using tap water irrigation (two treatments). In both treatments, the sprouts were raised in continuous light in a temperature-controlled room for a period of 7 days. There was no difference in DM loss after 7 days of sprouting. The DM losses after 7 days of sprouting were 16.4 vs. $13.3 \%$ for tap water irrigation and hydroponic nutrient solution, respectively (Dung et al., 2010).

Hydroponic barley green fodder (BGF) that was included to provide 22.8 percent of the total diet on dry matter basis. Seed grade barley was grown in a hydroponics chamber system where the growth period was adjusted for 6 days (Fazaeli et al., 2011). Productivity and nutritive value of barley green fodder yield in hydroponic system and reported that there was a significant difference $(p<0.05)$ between the original barley grain and hydroponics fodder barley for DM, where it was less than 20 per cent in case of green fodder (GF) but more than 90 per cent in initial grain. The DM content of GF was significantly $(p<0.05)$ reduced by increasing the growing periods from 6 to 7 days (Fazaeli et al., 2012).

Nutrient changes with growth of hydroponics fodder Wheat and they reported that Wheat hydroponics is more nutritious than conventional type fodder; as it contains more crude protein (13.30-13.6 vs.10.70-11.14 \%), ether extract (3.27-3.50 vs. 2.20-2.30 \%), nitrogen free extract (66.70-75.32 vs.51.80$53.54 \%$ ) but less crude fiber (6.37-14.10 vs. $22.25-25.90 \%)$, total ash (1.75-3.80 vs. 9.40$9.84 \%)$ and acid insoluble ash (0.30-0.57 vs. 1.03-1.40 \%) (Naik et al., 2013). Determine the effects of different harvesting times on the nutritional value of barley fodder produced in 
hydroponic system. Barley fodders were harvested on the 4th, 7th, 10th and 13th days following sowing date. Analysis performed for determining the chemical composition and organic matter digestibility (OMD) and ME content with in vitro gas production technique (Akbag et al., 2014).

The effect of feeding hydroponically sprouted or nutritive Wheat and barley fodder for Konkan Kanyal goats. The experiment was conducted at the Instructional livestock farm, College of Agriculture, Dapoli-415712, District Ratnagiri (M.S), India. Eighteen growing male kids of 3-7 months old with initial body weight of $11.01 \pm 0.26 \mathrm{Kg}$ were divided into six treatments (3 animals each) randomly to receive one of the treatment diets viz. T0-Finger millet straw(FMS)100\%; T1FMS + hydroponic Wheat fodder (HMF) 80\%:20\%; T2-FMS + hydroponic barley fodder(HBF) 80\%:20\%; T3-FMS + HMF 60\%:40\%; T4-FMS + HBF 60\%:40\%; T5$\mathrm{FMS}+\mathrm{HMF}+\mathrm{HBF}$ 60\%:20\%:20\% for 97 days (Kide et al., 2015).

Hydroponically grown Wheat fodder had shown increased nutrient profile such as crude protein, ether extract and nitrogen free extract along with improved fresh fodder weight and less fiber content than conventional Wheat fodder (Gebremedhin et al., 2015).

The study recommended that using barely cultivar Giza 127 for the highest sprout yield production, crude fat, fiber, ash contents and water use efficiency in intensive hydroponic system. For maximizing the yield per area unit, water use efficiency and matching food security needs, the intensive hydroponic system for barely sprout production as a green fodder could be fruitful to achieve these targets (Emam, 2016). Hydroponics technique in Algeria through: (i) assessing the nutritional value of forage, (ii) impact of use of the green on milk production and finally, (iii) estimate the economic value of this technique. The results obtained have shown the multiplication of the fresh weight of the green by a factor of 6 , relative to the weight of the seed. Total Nitrogen Content (TNC) was higher in green plant $(27.10 \%)$ than in roots $(12.92 \%)$ (Kaouche et al., 2016).

\section{Economics of feeding Hydroponic Fodder}

Hydroponics fodder can be grown in low cost green houses with locally available or homegrown grains. To produce one $\mathrm{Kg}$ of fresh hydroponics Wheat fodder (7 day) requires about 1 litre water (if water is reused) to 3 (if water is not reused) in high-tech greenhouse system. Many farmers revealed fresh yield up to 8-10 folds can be obtained. The cost of production of the hydroponics fodder was about Rs. $2-3 / \mathrm{Kg}$ fresh fodder if seed was home grown; however, if seed was purchased from market, the cost of production was a bit higher as Rs 3-3.50 (Naik et al., 2013). Produced green fodder especially in dry season by sprouting white corn seeds on roughages like date palm leaves (Phoenix dactylifera L.) and potatoes peels waste (Solanum tuberosum) as a media mixture (with 50 per cent PPW and 50 per cent DPL) and high nutritive value for the animals and environment friendly as well as reduce the cost of feeding by utilizing dried desert and agriculture by products with simple methodology using crop sprouts and employ to produce forage feed instead of causing pollution (Helal and Hassan, 2013).

Feeding of hydroponics to milking cows indicates an increase in milk yield by $0.5-2.5$ litres per animal per day and in the net profit of by Rs. 25-50 due to feeding of hydroponics fodder to their dairy animals. In addition, 26 increases the Fat and SNF content of the milk, improvement in health and conception rate of the dairy animals, reduction in cattle feed requirement by 25 per cent, increase in taste 
(sweetness) of the milk, whiter in colour of milk, requirement of less space and water, freshness and high palatability of the hydroponics fodder (Naik et al., 2014).

The biological and economical values of hydroponic barley (HB) on lactating Awassi ewes

A total of 48 lactating ewes were used in a feeding trial in two groups. The first treatment group was fed a regular lactation TMR ration while ewes in the second treatment were fed similar ration except that regular wheat hay was totally replaced by $\mathrm{HB}$ for 120 days feeding trial. At the end of the experiment they observed that the green fodder yield in 8 days germination cycle was $7.5 \mathrm{Kg}$ per $1 \mathrm{Kg}$ barley grains of green fodder (Saidi and Omar, 2015).

The cost of hydroponics green feed varies with the size of the machine. The operational cost of the green feed in the machine APH1000 (Modelnumber) would range between Rs 4.50 to 5.00 per $\mathrm{Kg}$. The cost of green feed included cost of barley seed (Rs $20 / \mathrm{Kg}$ ), cost of nutrient solution, labour cost, electricity charges and miscellaneous expenses. The total expenditure (Rs/d/calf) was lowest in treatment T1 (Rs. 29.60) as compared to other groups but the cost of per $\mathrm{Kg}$ weight gain was lowest in T2 (Rs $61.45 / \mathrm{Kg}$ ) followed by T3 (Rs $75.7 / \mathrm{Kg}$ ). There was a reduction of $33 \%$ in feeding cost per $\mathrm{Kg}$ weight gain/calf/day in T2 compared to T1 (Rs 91.70/Kg) (Swati Verma et al., (2015).

\section{Application of Hydroponics}

Conservation of water

Reduction in the amount of land

Reduced labour requirement

Reduction in growth time of green fodder

Green fodder round the year

Increasing of nutritive value of fodder
Natural feed for animals

Enhancement of milk production

Minimizing loss of fodder

In hydroponic structure production of green nutritive fodder is more than open field and also uses less water and land. The land saves $65-75 \%$ than convention fodder. The temperature inside the hydroponic structure was found $8^{0} \mathrm{C}-10^{0} \mathrm{C}$ less than outside temperature, which is favorable for the growth of hydroponic fodder and the relative humidity inside hydroponic structure was found $55-65 \%$ more as compare to open field. The relative humidity was maintained between $60-70 \%$ for optimum growth of fodder in hydroponic structure. The average height of plant was recorded maximum in the hydroponic structure. Plant height in hydroponic structure was 4-5 times more as compared to the open field. Also all nutritive values is more as compare to open field.

\section{References}

Ajmi A. A., A. A. Salih, I. Kadim, Y. Othman (2009) Yield and water use efficiency of barley fodder produced under hydroponic system in gulf countries using tertiary treated sewage effluents. Journal of Phytology, 1(5): 342-348.

AkbagA. I., B. S. Turkmen, B. Baytekin, A. Y. Yurtman (2014) Effects of Harvesting Time on Nutritional Value of Hydroponic Barley Production. Turkish Journal of Agricultural and Natural Sciences, Special Issue: 2:1761-1765.

AOAC, (2000) Official Methods of Analysis. $17^{\text {th }}$ edn. Association of Official Analytical Chemists, Washington DC.

Devika S. V., S. K. Khamuruddeen, S. K. Khamurunnisa, J. Thota, K. Shaik (2014). Arduino Based Automatic Plant Watering System. International Journal of Advanced Research in Computer 
Science and Software Engineering 4(10), October - 2014, pp. 449-456

Dung D. D., I. R. Godwin and J. V. Nolan (2010) Nutrient content and in sacco digestibility of barley grain and sprouted barley. Journal of Animal and Veterinary Advances 9(19): 2485-92.

El-Morsy A. T., M. Abul-Soud and M. S. A. Emam (2013) Localized hydroponic green forage technology as a climate change adaptation under Egyptian conditions. Research Journal of Agriculture and Biological Sciences, 9(6): 341-350.

Emam M. S. A. (2016) The Sprout Production and Water use Efficiency of some Barley Cultivars under Intensive Hydroponic System. Middle East Journal of Agriculture Research, 5(2):161-170.

Fazaeli H., H. A. Golmohammadi, A. A. Shoayee, N. Montajebi, and Sh. Mosharraf (2011). Performance of Feedlot Calves Fed Hydroponics Fodder Barley. J. Agr. Sci. Tech. (2011) Vol. 13: 367-375 367.

Fazaeli H., H. A. Golmohammadi, S.N. Tabatabayee and M. Asghari-Tabrizi (2012) Productivity and Nutritive Value of Barley Green Fodder Yield in Hydroponic System, World Applied Sciences Journal 16 (4): 531-539.

Florence M., M. John, G. George, V. John and N. Yigzaw, Economic efficiency of milk production among small scale dairy farmers in Mukurweini,

Gaikwad S.P. (2015) Hydrophonic Low Cost Structure. Sakal Papers Pvt. Ltd., Pune. 1st Edn. Dec. 2015. pp 41-54.

Gebremedhin W. K., B. G. Deasi and A. J. Mayekar (2015) Nutritional evaluation of hydroponically grown Barley fodder. Journal of Agricultural Engineering and Food Technology 2(2):86-89.

Ghazi N. Al-Karaki and N. Al-Momani (2011) Evaluation of some barley cultivars for green fodder production and water use efficiency under hydroponic conditions. Jordan Journal of Agricultural Sciences, 7(3): 448-456.

Helal, H. G. and Mona M. Hassan (2013). Sprouted Zea mays on date palm leaves and potatoes peel waste mixture and its effects on performance of desert goats under dry season in Sinai. J. Animal and Poultry Prod., Mansoura Univ., Vol.4 (3): 117 - 132, 2013.

Ishrath P. K., and Usha. C. Thomas (2016) Recent Trends in Fodder Production and Preservation. Advances in Life Sciences 5(10), Print: ISSN 2278-3849, 3912-3921, 2016.

Kamat V. R., V. Kulkarni, V. Raghavendra and M. Veerangouda (2018) Design and Development of Solar Assisted Hydroponic Maize Fodder Gadget. International Journal of Current Microbiology and Applied Sciences ISSN: 2319-7706 Volume 7 Number 03 (2018).

Kaouche S., A. Adjlane, A. Serir, M. Bafdel and R. Benhacine (2016) TechnoEconomic Approach to Hydroponic Forage Crops: Use for Feeding Dairy Cattle Herd. Journal of Applied Environmental and Biological Sciences. 6(3), 83-87.

Kide W., B. Desai, J. Dhekale (2015). Feeding Effects of Maize and Barley Hydroponic Fodder on Dry Matter Intake, Nutrient Digestibility and Body Weight Gain of Konkan Kanyal Goats. Life Sciences International Research Journal: Volume 2 Issue 2 (2015).

Lamnganbi M. and U. S. Surve (2017) Biomass yield and water productivity of different hydroponic fodder crops. Journal of Pharmacognosy and Phytochemistry 2017; 6(5): 1297-1300.

Leontovich V. P. and M. A. Bobro (2006). Technology of Continuous Growing of Hydroponic Fodder. Russian 
Agricultural Sciences, 2007, Vol. 33, No. 4, pp. 239-241.

Matos J., J.S. Paulo and M.B. Torres (2015) an automatic mechanical system for hydroponics fodder production. The Romanian review precision mechanics, optics \& mechatronics, 47:63-71.

Mishra R. L. and P. Jain (2015) Design and Implementation of Automatic Hydroponics System using ARM Processor. International Journal of Advanced Research in Electrical, Electronics and Instrumentation Engineering. 4(8) 6935-6940.

Naik P. K, M. Karunakaran, E. B. Chakurkar, B. K. Swain and N. P. Singh (2016) Digestibility of nutrients in crossbred heifers supplemented with hydroponically sprouted Wheat grains. Indian Journal of Animal Sciences (in press).

Naik P. K., B. D. Dhawaskar, D. D. Faterpekar, B. K. Swain, E. B. Chakurkar and N. P. Singh (2016) yield and nutrient content of hydroponics cowpea sprouts at various stages of growth. Indian Journal of Animal Sciences 86 (12): 118-00.

Naik P. K., B. K. Swain and N. P. Singh (2015) Review-production and utilization of hydroponics fodder. Indian Journal of Animal Nutrition. 32(1): 1-9.

Naik P. K., M. Karunakaran, B. K. Swain, E. B. Chakurkar and N. P. Singh (2016) Voluntary intake and digestibility of nutrients in heifers fed hydroponics Wheat (Zea wheat L.) fodder. Indian Journal of Animal Nutrition (in press).

Naik P. K., R. B. Dhuri, B. K. Swain and N. P. Singh (2012) Nutrient changes with the growth of hydroponics fodder Wheat. Indian Journal of Animal Nutrition.29: 161-63.

Naik P. K., R. B. Dhuri, M. Karunakaran, B. K. Swain and N. P. Singh (2013)
Hydroponic technology for green fodder production. Indian Dairyman.65: 54-58.

Naik P.K., B.D. Bhawaskar and D.D. Fatarpekar (2017) Effect of feeding hydroponic Wheat fodder replacing Wheat of concentrate mixture partially on digestibility of nutrients and milk production in lactating cows. Indian Journal ofAnimal Science. 87(4): 452455.

Naik P.K., B.K. Swain, E.B. Chakarkar and N.P. Singh (2017) Effect of seed rate on yield and proximate constituents of different parts of hydroponics Wheat fodder. Indian Journal of Animal Science. 87(1) 109-112.

Nayak A. K. and K. V. Ramanarao (2014) Estimation of wind load on a greenhouse and evaluation of its structural stability. International Journal of Agricultural Engineering. 7(2): 461-466.

Nikolaevna S. O. (2015) The Study of The Process of Seed Dispersal over the Plant Growing Surface of a Tray in Hydroponic System. UDC 636.085.51:631.589.2):621.492.

Pack M. and K. Mehta (2012). Design of affordable greenhouses for East Africa, IEEE Global Humanitarian Technology Conference.

Policarpo E. R., E. M. Luis Manuel and P. M. Claudio Arturo (2007) Hydroponic forage wheat production. African Crop Science Conference Proceedings Vol. 8. pp. 1915-1916.

Saidi M. A., J. A. Omar (2015).The Biological and Economical Feasibility of Feeding Barley Green Fodder to Lactating Awassi Ewes. Open Journal of Animal Sciences, 2015, 5, 99-105.

Sardare M. D., and S. V. Admane (2013) A review on plant without soilhydroponics. International Journal of Research in Engineering and Technology. 2 (03):299-304. 
Sihombing P., N. A. Karina, J. T. Tarigan and M. I. Syarif (2017) Automated hydroponics nutrition plants systems using arduinouno microcontroller based on android. Journal of Physics: Conf. Series 978

012014:10.1088/1742-6596/978.

Singh N. P., (2011) Technology for production and feeding of hydroponics green fodder, I.C.A.R. research complex for Goa, old Goa.

Snow A. M, A. E. Ghaly and A. Snow (2008) A Comparative Assessment of Hydroponically Feed American Journal of Agricultural and Biological Sciences 3 (1): 364-378.

Soder K. J., B. J. Heins, H. C. Jones, A. N. Hafla, and M. D. Rubano. Evaluation of fodder production systems for organic dairy farms. The Professional Animal Scientist 34:75-83.

Verma S., A. Singh, A. Karla and M. Saxena (2015). Effect of feeding hydroponics barley (Hordeum vulgare) fodder on nutrient utilization, growth, blood metabolites and cost effectiveness in Haryana male calves. Indian Journal Animal Nutr. 2015.32(1): 10-14.

\section{How to cite this article:}

Rahul G. Tayade and Sonali J. Chavan. 2018. Development and Performance of Pipe Framed Hydroponic Structure for Fodder Crop: A Review. Int.J.Curr.Microbiol.App.Sci. 7(11): 341350. doi: https://doi.org/10.20546/ijcmas.2018.711.043 